\title{
Results of Fracture Mechanics Analyses of the Ederer Cranes in the Device Assembly Facility Using Reduced Static Fracture-Toughness Values
}

\author{
Edward N.C. Dalder
}

\section{DISCLAIMER}

This report was prepared as an account of work sponsored by an agency of the United States Government. Neither the United States Government nor any agency thereof, nor any of their employees, makes any warranty, express or implied, or assumes any legal liability or responsibility for the accuracy, completeness, or usefulness of any information, apparatus, product, or process disclosed, or represents that its use would not infringe privately owned rights. Reference herein to any specific commercial product, process, or service by trade name, trademark, manufacturer, or otherwise does not necessarily constitute or imply its endorsement, recommendation, or favoring by the United States Government or any agency thereof. The views and opinions of authors expressed herein do not necessarily state or reflect those of the United States Government or any agency thereof.

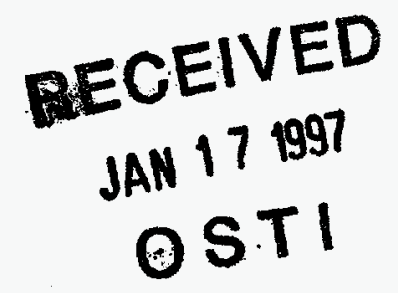

November 30, 1996

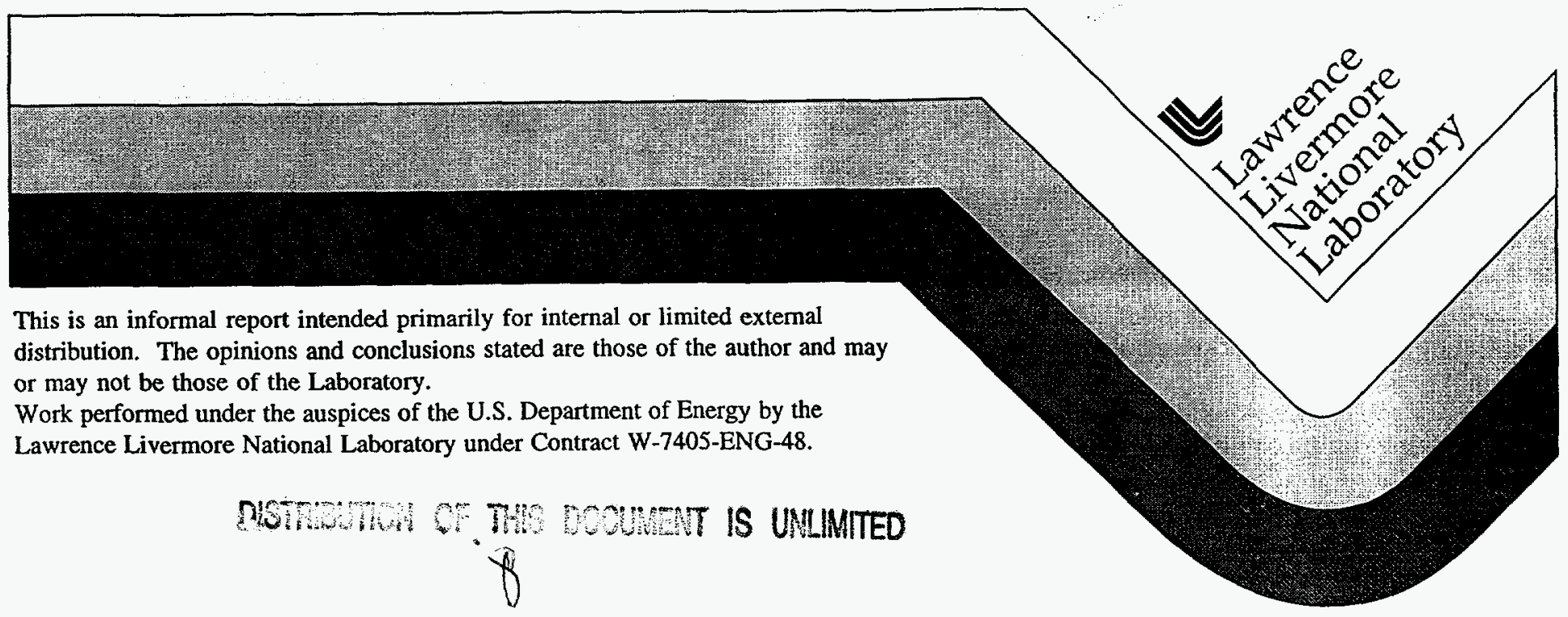




\section{DISCLAMMER}

Portions of this document may be illegible in electronic image products. Images are produced from the best available original document. 


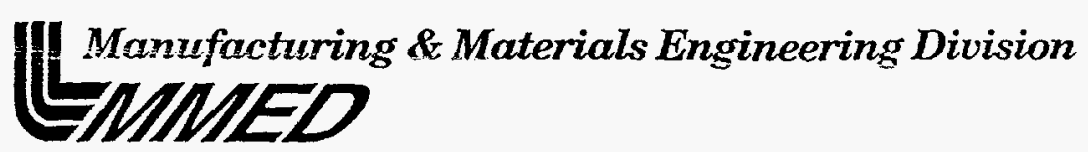

- November 4, 1996

TO: $\quad$ A. M. Davito

FROM: $\quad$ Edward N.C. Dalder

SUBJECT: Effect of Decreased Static Fracture Toughness on Fracture Mechanics Analyses of the Ederer Cranes in the Device Assembly Facility

Abstract: Per your verbal request, the effects of a decreased static fracture-toughness of $25 \mathrm{KSI} \sqrt{\mathrm{in}}$, down from the $45 \mathrm{KSI} \sqrt{\mathrm{in}}$ value used in the previous fracture-mechanics analyses of the Ederer cranes in the Device Assembly Facility, were examined to see what effects, if any, would be exerted on the fatigue crack growth and fracture behavior of the cranes. In particular, the behavior of the same 3 critical locations on the lower flanges of the load beams of the Ederer 5 ton and 4 ton cranes, were examined, with the reduced static fracture-toughness value of

$25 \mathrm{KSI} \sqrt{\mathbf{i n}}$. Based on these results, it appears that:

1. Small reductions in calculated fatigue life (less than or equal to $0.524 \%$ ) or calculated flaw-length (less than or equal to 16.7\%) are expected to occur as a result of reducing the static fracture-toughness of the ASTM A-36 steel used in construction of the cranes.

2. Propagation of a 1/4" long flaw, previously undetected by non-destructive examination (NDE), to a length sufficient to cause structural failure of either flange, should not occur in at least 100 times the postulated operating scenarios for each crane; and

3. Should each crane undergo annual inspection, any surface flaw with a length greater than $0.53 "$ should be removed and repaired by approved repair procedures.

Introduction: Per A. Davito's verbal request, fracture mechanic analyses were performed for the highly-loaded lower flange on the Ederer 5 ton crane (Ederer Dwg. No. Al4855) and Ederer 4 ton or "Polar" crane (Ederer Dwg. No. A14937) using loads and stress information contained in Refs. 1-2. This work was done to determine the effects, if any, of the aforementioned reduction in $\mathrm{K}_{\mathrm{IC}}$ for the ASTM A-36 steel plates used in manufacture of these flanges, but with the static fracture-toughness $\left(\mathrm{K}_{\mathrm{IC}}\right)$ value reduced from $45 \mathrm{KSI} \sqrt{\mathrm{in}}$ used in the previous set of analyses (Ref. 3) to a value of $25 \mathrm{KSI} \sqrt{\mathrm{in}}$ as mandated in both the LLNL "Design Safety Standards" (Ref. 4) and "NTED Design Guide" (Ref. 5).

Procedure: First, Refs. 1-2 were reviewed, stress-information for the two cranes were obtained and summarized in Table 1. The maximum value of stress-component was selected as the stressvalue to be used in the fracture-mechanics calculations, to incorporate a measure of conservatism. Since the basis of these calculations was based on the growth of a pre-existing flaw under the action of cyclic stresses, it is appropriate to describe how such analyses are performed.

Crack growth analysis is based on the similitude provided by the stress intensity factor $\mathrm{K}$, which provides a full description of the crack tip stress field, provided there is little plasticity. $\mathrm{K}$ can be expressed as 


$$
K=\sigma \sqrt{\pi a} \beta
$$

where a is the crack size (or half the crack size when the crack has two tips); sigma is the nominal (remote) stress, and beta a factor accounting for geometry. It should be emphasized that sigma is the nominal stress in a remote section not affected by the crack, as effects of the reduced area in the cracked section are accounted for in beta, a non-dimensional function of crack size and other geometrical parameters. Such beta values can be obtained from stress intensity handbooks such as Refs.6-8.

The stress intensity provides a full description of the elastic crack tip stress field. If two cracks in the same material, but of different length and in different structural configuations, are subject to equal $\mathrm{K}$, then the stress fields at both crack tips are identical. Hence, both cracks behave in the same manner, i.e., show the same rate of growth. This leads to:

$$
\frac{\mathrm{d} a}{d N}=f(\Delta K, R)
$$

where da/dN is the rate of propagation, $N$ the number of cycles, $K_{\max }-K_{\min }$ the range of stress intensity in a load cycle, and $\mathrm{R}=\mathrm{K}_{\min } / \mathrm{K}_{\max }=\sigma_{\min } / \sigma_{\max }$ is the so-called "stress ratio".

According to equation (2), every time a certain combination of $\mathrm{K}$ and $\mathrm{R}$ appears, the amount of crack extension is the same. The function $f(K, R)$ is obtained from crack growth tests on specimens in the laboratory. Data for many materials can be found in the literature, especially in Refs. 9-10.

The objective of crack growth analysis is to obtain a crack propagation curve for a crack in a structure. This requires integration of

$$
N=\int \frac{d a}{(d a / d N)}=\int \frac{d a}{f(\Delta k, R)}
$$

Since $f(K, R)$ is a complicated function, beta for the structural crack a complicated function of a, and the stress range is different in every load cycle, the integration has to be performed numerically, using a computer program such as "Fatkrak" (Ref. 11)

When different load cycles have different stress-ranges, similitude may no longer be provided by $K$. In such cases, $f(K, R)$ no longer provides the correct da/dN. This is called "load interaction". In most cases, the net load interaction effect is slower crack growth, which is called "crack retardation". Although load interaction may be explained qualitatively, there is no wholly satisfactory way to qualitatively account for the effect. The net load interaction effect is almost always a retardation.

The user has to specify the function $f(K, R)$. Several empirical equations are available for this function, none of which has a theoretical basis. The simplest curve fitting equation is known as the Paris equation (Ref. 12) which assumes a log-log-linear relation between $\mathrm{K}$ and $\mathrm{da} / \mathrm{dN}$ : 


$$
\frac{\mathrm{d} a}{d N}=C_{p}(\Delta K)^{m_{p}}
$$

where $\mathrm{Cp}$ and $\mathrm{m}_{\mathrm{p}}$ are constants for a material and test-conditions (temperature, and environment). This equation ignores the effect of $R$, which is acceptable for our situation since $R=0$ (minimum load $=0$ ). See Appendix $A$ for additional information on determination of $C_{p}$ and $M_{p}$, the "Paris Law" constants for ASTM A-36 steel at room temperature.

Hence, the input-information for operation of FATKRAK consists of:

1. The choice of flaw-configuration (Fig. 1), in our case, a semi-elliptical flaw with aspect-ratio of 0.25 , oriented on the bottom surface of the lower flange of the crane-beam for locations (or "points") 0 and 1 (Fig. 2b), or oriented on the top surface of the lower flange of the crane-beam for location 2 (Fig. 2a) (choosing such a flaw-configuration determines the stress-intensity expression (Ref. 8)

$$
K_{I}=\sigma \sqrt{\pi a}\left\{1.12\left[\frac{1.05+10\left(0.6-\frac{a}{2 c}\right)}{\sqrt{1+8\left(\frac{a}{x}\right)^{2}}}\right]\left(\frac{a}{w}\right)^{3}\right\}
$$

2. Initial flaw-size, ranging from flaw-depth values ("a") of 0.063 " to $1.0^{\prime \prime}$

3. Stress $(\sigma)$ values from Table 1 ;

4. Final defect-size, in terms of the critical value of flaw-depth, a, at which rapid; unstable failure occurs;

5. Paris-Law constants of $C_{p}=3.98 \times 10^{-12}$ in./cyc and $M_{p}=4.86$, from Appendix $A$; and

6. Width (288") and thickness (1.0" for the 5 ton crane, or $0.75^{\prime \prime}$ for the 4 ton crane) of the flange from Fig. 1.

A typical table of output is presented in Table 2, wherein progressively-larger flaw-dimensions are tabulated for increasing numbers of loading cycles. The results of 5-8 such runs, using increasing values of the initial flaw-size, a, as the input-parameter, are plotted in Fig. 3. (Additional plots for other load-cases and locations are contained in Appendix B). Information such as Fig. 3 is used to set flaw-size units for safe operation, periodic inspection, and "Retirement for Cause"- based fracture safety as follows:

1. Determine the annual number of load-cycles (200-400 per Ref. 13) and total number of loadcycles $(12,000)$ at the "end-of-life", of 30 years (Ref. 13);

2. Enter Fig. 3 at the indicated number of cycles, say 400 , and proceed vertically upward until the desired curve of "flaw dimension vs. cycles" is reached.

3. Proceed to the left until the "dimension of flaw" axis is reached, and read off the indicated flaw dimension for the chosen number of cycles of loading. For the "initial flaw length", a quantity measurable by NDE, the value is $2.6^{\prime \prime}$.

The significance of this "initial flaw length", (2c), of 2.6 " is that after 400 applications of a tensile stress of $11.6 \mathrm{ksi}$, rapid failure will occur. Proceeding in a similar manner with the computed information summarized in Figs. B1-B5, the information in Tables 3-4 was generated.

Considering Table 3 first, it is seen that initial surface flaw-lengths on the order of 2.75-3.40 inches will cause failure in 200-400 cycles, a typical year's worth of operation. For a 30 year usage period, hereafter referred to as "a lifetime", initial surface flaw-lengths to cause failure drop to the order of $1.10-2.55^{\prime \prime}$. 
Consider Table 4, wherein is summarized the number of loading-cycles needed to grow a small flaw, one with initial surface-length of $0.25^{\prime \prime}$, to sizes great enough to cause structural-failure of the lower flange. The initial surface-length value of 0.25 " was chosen on the basis of it being the largest length flaw that might not be detected by common NDE methods, such as magnetic-particle inspection or dye-penetrant methods, during periodic inspection of the cranes (Ref. 13). Note that, under such conditions, the predicted cyclic lives to failure are of the order $10^{6}-10^{8}$ cycles of load, or 104 to 1290 lifetimes of crane usage. Hence, growth of a "reasonably small" undetected flaw to cause structural failure of the lower flange of either crane's beam is unlikely, even at a reduced static fracture-toughness value of $25 \mathrm{KSI} \sqrt{\mathrm{in}}$

Another more quantitative way of assessing the degree of conservatism introduced in the Ref. 3 fracture-mechanics analysis is to consider the "Margin of Conservatism", or "M. C.", introduced by the assumption of a static fracture-mechanics value of $25 \mathrm{KSI} \sqrt{\mathrm{in}}$, where:

(6) Margin of Conservatism $=1-\frac{\text { Characteristic Flaw Dimension for } \mathrm{K}_{\mathrm{IC}}=25 \mathrm{KSI} \sqrt{\mathrm{in}}}{\text { Characteristic Flaw Dimension for } \mathrm{K}_{\mathrm{IC}}=45 \mathrm{KSI} \sqrt{\mathrm{in}}}$

For the "characteristic flaw-dimension" was chosen the length of the crack, $2 \mathrm{C}$, as shown in Figure 2C. Crack-length was chosen because it is a parameter that can readily be measured at the beginning of operation ("initial flaw-length"), or at any time in the operational lives of the cranes up to the onset of rapid fracture ("final flaw-length"). In Table 5 is summarized the initial flawlength values obtained from analyses conducted with a static fracture-toughness of $45 \mathrm{KSI} \sqrt{\mathrm{in}}$, hereafter described as the "normal fracture toughness case", and initial flaw length values obtained from analyses conducted with a static fracture of $25 \mathrm{KSI} \sqrt{\text { in }}$, hereafter described as the "minimum fracture-toughness case." Substituting these values of "initial flaw-length" into Eqn. 5 produced the array of "margin of conservatism" values presented in the far-right side of Table 5. Proceeding in a similar manner, the "margin of conservatism" array, based on "final flaw length" as the characteristic flaw-dimensoin, was generated, and is presented in Table 6.

Considering the "margin of conservatism" values based on "initial flaw length", the following trends can be obtained from an examination of Table 5:

1. Margin of conservatism values, based on a year's operation (200-400 cycles) are small, and range from 0.056 to 0.167 or $5.6 \%$ to $16.7 \%$. In general, the margin of conservatism values increased with cyclic life ( 200 cycles to 400 cycles) for the 5 ton crane, but decreased with the same increase in cyclic life for the 4 ton crane.

2. Margin of conservatism values, based on the full 30 years or 12,000 cycles design-life were small, ranging from 0 to 0.088 , or 0 to $8.8 \%$

Considering the "margin of conservatism" values based on "final flaw length", or flaw-length at which rapid fracture would occur, the following trends can be obtained from an examination of Table 6:

1. Based on a year's operation (200-400 cycles), the margin of conservatism values ranged from 0.079 to 0.160 , or $7.9 \%$ to $16.0 \%$. In general, the margin of conservatism values increased with increasing cyclic life ( 200 cycles to 400 cycles), for the 5 ton crane, but decreased with the same increase in cyclic life for the 4 ton crane.

2. Based on the full 30 year design-life, or 12,000 cycles, margin of conservatism values ranged from 0 to 0.122 , or 0 to $12.2 \%$. 


\section{Discussion:}

1.Setting an "Initial Flaw Length" for Possible Removal and Repair

Since periodic inspections of other sub-systems of the cranes are likely to be performed on an annual basis (Ref. 13), i.e. every 400 cycles, detection of a flaw with a surface-length of $0.55^{\prime \prime}$ (half the surface-length of a "fatal flaw") for the most highly-stressed location could be cause for retirement of the crane-beam. The choice of a factor of two reduction in flaw-length is based on the A.S.M.E. Boiler and Pressure Vessel Code Section III (Nuclear) reduction factors on fatigueperformance (Ref. 14), i.e. the greater of a factor of 2 on strain-range (or stress-range) or a factor of 20 on cyclic life. In this treatment, the "strain-range; stress-range" parameter has been replaced by "initial flaw length". The choice of using half of the initial flaw-length of the most highlystressed location; location 1 on the 4 ton crane, was done to introduce a single "go-no go" parameter rather than having 6 such values ( 3 per crane), that may cause confusion among inspectors. Should it be considered desirable by the D.A.F. operations management, detection of a flaw with a surface-length of $0.55^{\prime \prime}$ might be made the point at which such a defect would be removed and replaced by suitable methods controlled by approved repair procedures.

2. Effect of Using a Reduced Static Fracture-Toughness on the Calculated Fatigue Lives of the Lower Flanges in the Ederer Cranes

Reducing the static fracture-toughness from $45 \mathrm{KSI} \sqrt{\mathrm{in}}$ to $25 \mathrm{KSI} \sqrt{\mathrm{in}}$ reduced the calculated cyclic lives to failure, for the case of a flaw with an initial-surface-length (2c) of 0.25 ", about $0.077 \%$ to $0.524 \%$, based on a comparison of the "number of operational lives ( 1 life $=12,000$ cycles to failure) in Table 4 of this report with the corresponding Table in the Ref. 3 report. See Table 7 for a line-by-line comparison.

\section{Conclusions:}

1. Fracture -mechanics analyses of 3 critical locations of the Ederer 5 ton crane and 4 ton crane in the Device Assembly Facility, using a "minimum fracture toughness value" of $25 \mathrm{KSI} \sqrt{\mathrm{in}}$ showed that:

a. Less than a $0.524 \%$ reduction in calculated cyclic life would occur, relative to previous analyses (Ref. 3) which used a "normal fracture toughness value" of $45 \mathrm{KSI} \sqrt{\mathrm{in}}$;

b. The use of lower fracture-toughness value in the afore-mentioned analyses introduced small conservatisms in the results of the analyses, typically $5.6 \%$ to $16.7 \%$ based on changes in initial flaw length, or $0-16 \%$ based on changes in final flaw length at fracture.

2.Even under the situations described herein for the analyses conducted using the "minimum fracture toughness value" of $25 \mathrm{KSI} \sqrt{\mathrm{in}}$, propagation to failure of a semi-elliptical surface crack with an aspect-ratio of 0.25 and an initial length of $0.25^{\prime \prime}$, should not occur in at least 100 times the assumed "operational life" of the crane-beam lower flange of either Ederer crane.

For additional information, please contact the undersigned at ext. 2-7270.

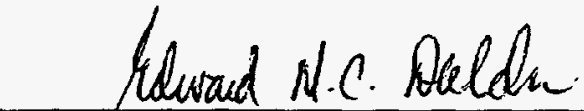

Edward N.C. Dalder

Materials Engineering \& Mechanics Section

Manufacturing \& Materials Engineering Division

Distribution:

J. Dini, L-342 


\section{References:}

1) L. Walker (RSN) to A. Davito (LLNL), fax , "Ederer Five Ton Crane," Control No. 00260, 9/22/95

2) L. Walker (RSN) to A. Davito (LLNL), fax, "Ederer Four Ton Crane," Control No. AOBID301,12/7/95

3) E. Dalder, "Results of Fracture Mechanics Analyses of the Ederer Cranes in the Device Assembly Facility", Lawrence Livermore National Laboratory, UCRL-ID-125068, 8/21/96.

4) J.J. Scott, "Design Safety Standards...Mechanical Engineering", Section 5.4., "Fracture Critical Components", Pg. 14, 9/15/95.

5) A.M. Davito, "NTED Design Guide", Report M-186, Rev. 1., Chapter 3, "Implementation of Fracture Control:, Pg 3-3, May 1993.

6) D. Rooke and D. Cartwright, "Handbook of Stress Intensity Factors," Her Majesty's Stationary Office (UK), London, 1976

7) H. Tada, P. Paris, and G. Irwin, "The Stress Analysis of Cracks Handbook," Del Research Corp., 1973

8) Y. Murakami (Editor), “Stress Intensity Factors Handbook," Pergammon Press, Vols., 1 \& 2, 1987, Vol. 3, 1992

9) W. F. Brown, Jr., "Aerospace Structural Metals Handbook,"CINDA/USAF CRDA Handbook Operation, Purdue University, Vols. 1-5, 1996 Edition

10) D. Skinn, J. Gallagher, A. Berens, P. Huber, J. Smith, "Damage Tolerant Design Handbook," WL-TR-94-4052, University of Dayton Research Institute, Volumes 1-4, Mary, 1994

11) D. Broek, "The Fracture Mechanic," User's Manual, A.S.M. International, 1986, pp. F5F80

12) P. Paris, "The Growth of Fatigue Cracks Due to Variations in Load," Ph.D. Thesis, Lehigh University, 1962

13) A. Davito (LLNL), Personal Communication, $6 / 96$

14) Anon, "Criteria of the ASME Boiler and Pressure Vessel Code for Design by Analysis in Sections III and VIII, Division 2," American Society of Mechanical Engineers, 1969 
Table 1: Stresses and Final Defect Sizes Used as Inputs to Fracture Mechanics Calculations Based on a Static Fracture-Toughness of $25 \mathrm{KSI} \sqrt{\mathrm{in}}$

\begin{tabular}{|c|c|c|c|c|c|c|c|c|}
\hline \multirow{2}{*}{$\begin{array}{l}\text { Crane } \\
\text { Type }\end{array}$} & \multicolumn{2}{|c|}{ Flaw Information } & \multirow{2}{*}{$\begin{array}{l}\text { Location } \\
\text { No. }\end{array}$} & \multicolumn{3}{|c|}{$\begin{array}{l}\text { Stress-Component } \\
\text { Information (KSI) }\end{array}$} & \multirow{2}{*}{$\begin{array}{l}\text { (5) Final } \\
\text { Defect Depth } \\
\text { (inches) }\end{array}$} & \multirow[b]{2}{*}{ Basis } \\
\hline & Type & Orientation & & $\sum \sigma_{x}$ & $\sum \sigma_{4}$ & $C_{y}-14$ & & \\
\hline \multirow[t]{6}{*}{5 Ton } & $\begin{array}{l}\text { Surface } \\
\text { Flaw }\end{array}$ & $\begin{array}{l}\text { Along the } \\
\text { Flange }\end{array}$ & zero & -5.84 & 7.5 & $(11.6 i$ & $0.70 .5^{\prime \prime}$ & $\sigma_{v m}$ \\
\hline & $\mathrm{a} / 2 \mathrm{c}=0.25$ & & & & & & & \\
\hline & & & one & 2.90 & 113.81 & 12.6 & $0.670^{\prime \prime}$ & $\sum \sigma_{4}$ \\
\hline & & & & & $=$ & & & \\
\hline & & & two & 5.84 & 6.411 & 6.14 & $0.835^{\prime \prime}$ & $\sum \sigma_{y}$ \\
\hline & & & & & -1 & & & \\
\hline \multirow[t]{6}{*}{4 Ton } & $\begin{array}{c}\text { Surface } \\
\text { Flaw }\end{array}$ & $\begin{array}{l}\text { Along the } \\
\text { Flange }\end{array}$ & zero & -4.05 & 12.1 & $\left(\begin{array}{l}15.0 \\
-2\end{array}\right.$ & $0.511 "$ & $\sigma_{Y M}$ \\
\hline & $\mathrm{a} / 2 \mathrm{c}=0.25$ & & & & & & & \\
\hline & & & one & 2.3 & 17.01 & 16.0 & $0.493^{\prime \prime}$ & $\sum \int_{4}$ \\
\hline & & & & & & & & \\
\hline & & & two & 4.63 & 111.21 & 9.75 & $0.566^{\prime \prime}$ & $\sum \sigma_{y}$ \\
\hline & & & & & & & & \\
\hline
\end{tabular}

Notes:

${ }^{\prime} 1 . \sum Q_{X}=$ Total stress in $X$ direction (Fig.')

2. $\Sigma \sigma_{4}=$ Total stress in $Y$ direction (Figi),

3. $\sigma_{y y}=$ Von Mises Stress $=\sqrt{\sigma_{x}^{2}+\sigma_{q}{ }^{2}-\sigma_{x} \sigma_{y}}$

4. Circled values of stress used as inputs to fracture mechanics calculation.

5. $\quad$ Based on $\mathrm{K}_{\mathrm{IC}}=25 \mathrm{KSI} \sqrt{\mathrm{in}}$ 


\section{TABLE TWO}

RUN 135, 5 TON CRANE, LOCATION ONE, FLAW IS A SEMI-ELLIPTICAL SURFACE CRACK WTH AN ASPECT-RATIO OF 0.25, ORIENTED ALONG THE LONG DIRECTION OF THE FLANGE, INITIAL FLAW-DEPTH IS 0.500", FINAL FLAW-DEPTH IS 0.670", SMAX IS $13.8 \mathrm{KSI}$, SMIN IS 0, SY IS $36 \mathrm{KSI}$, MINIMUM FRACTURE-TOUGHNESS CASE

$\begin{array}{ccccc}\text { CRACK LENGTH } & \text { CRACK DEPTH } & \text { CYCLES } & \text { CYCLES } & \text { BETA } \\ 1.0000 " & 0.5000 " & 0 & 0 & 1.438 \\ 1.0019 & 0.5101 & 397 & 397 & 1.444 \\ 1.0040 & 0.5203 & 769 & 769 & 1.455 \\ 1.0062 & 0.5308 & 1116 & 1116 & 1.468 \\ 1.0085 & 0.5414 & 1439 & 1439 & 1.480 \\ 1.0110 & 0.5523 & 1741 & 1741 & 1.493 \\ 1.0137 & 0.5634 & 2021 & 2021 & 1.507 \\ 1.0165 & 0.5747 & 2281 & 2281 & 1.521 \\ 1.0195 & 0.5863 & 2523 & 2523 & 1.536 \\ 1.0226 & 0.5981 & 2747 & 2747 & 1.551 \\ 1.0260 & 0.6101 & 2954 & 2954 & 1.567 \\ 1.0296 & 0.6224 & 3146 & 3146 & 1.583 \\ 1.0334 & 0.6349 & 3322 & 3322 & 1.600 \\ 1.0375 & 0.6476 & 3486 & 3486 & 1.618 \\ 1.0417 & 0.6606 & 3636 & 3636 & 1.636 \\ 1.0440 & 0.6739 & 3706 & 3706 & 1.645\end{array}$

FATKRAK2


Table 3: Initial and Final Lengths of Semi-Eliptical Cracks (Aspect Ratio $=0.25$ ) That Will Cause Failure of the Lower Flange of the Ederer Five Ton and Four Ton

Cranes When Cranes are Cyclically - Loaded, Based on a Static Fracture-

Toughness of $25 \mathrm{KSI} \sqrt{\mathrm{in}}$

\begin{tabular}{|c|c|c|c|c|c|c|c|c|}
\hline \multirow{2}{*}{$\begin{array}{l}\text { Crane } \\
\text { Type } \\
\end{array}$} & \multirow{2}{*}{$\begin{array}{c}\text { Location } \\
\text { No. }\end{array}$} & \multirow{2}{*}{$\begin{array}{l}\text { Range of } \\
\text { Stresses }\end{array}$} & \multicolumn{3}{|c|}{$\begin{array}{l}\text { (1) Initial Flaw-Length to } \\
\text { Cause Failure in Indicated } \\
\text { Number of Cycles }\end{array}$} & \multicolumn{3}{|c|}{$\begin{array}{l}\text { Final Flaw Length to } \\
\text { Cause Failure in Indicated } \\
\text { Number of Cycles }\end{array}$} \\
\hline & & & 200 & 400 & 12,000 & 200 & 400 & 12,000 \\
\hline \multirow[t]{4}{*}{5 Ton } & zero & $\begin{array}{c}0-11.6 \\
\text { KSI }\end{array}$ & $2.60^{\prime \prime}$ & $2.50^{\prime \prime}$ & $1.90^{\prime \prime}$ & $2.70^{\prime \prime}$ & $2.65^{\prime \prime}$ & $2.00^{\prime \prime}$ \\
\hline & & & & & & & & \\
\hline & one & $0-13.8$ & $2.50^{\prime \prime}$ & $2.40^{\prime \prime}$ & $1.55^{\prime \prime}$ & $2.55^{\prime \prime}$ & $2.45^{\prime \prime}$ & $1.85^{\prime \prime}$ \\
\hline & two & $0-6.41$ & $3.20^{\prime \prime}$ & $3.10^{\prime \prime}$ & $2.55^{\prime \prime}$ & $3.50^{\prime \prime}$ & $3.40^{\prime \prime}$ & $2.90^{\prime \prime}$ \\
\hline \multirow[t]{4}{*}{4 Ton } & zero & $0-15$ & $1.80^{\prime \prime}$ & $1.75^{\prime \prime}$ & $1.25^{\prime \prime}$ & $1.90^{\prime \prime}$ & $1.85^{\prime \prime}$ & $1.40^{\prime \prime}$ \\
\hline & & & & & & & & \\
\hline & one & $0-17$ & $1.75^{\prime \prime}$ & $1.70^{\prime \prime}$ & $1.10^{\prime \prime}$ & $1.85^{\prime \prime}$ & $1.75^{\prime \prime}$ & $1.30^{\prime \prime}$ \\
\hline & two & $0-11.2$ & $2.00^{\prime \prime}$ & $1.95^{\prime \prime}$ & $1.60^{\prime \prime}$ & $2.10^{\prime \prime}$ & $2.05^{\prime \prime}$ & $1.70^{\prime \prime}$ \\
\hline & & & & & & & & \\
\hline
\end{tabular}

Notes:

(1) For a semi-eliptical surface-crack with an aspect-ratio of 0.25 
Table 4: Number of Cycles Needed to Grow a Semi-Eliptical Flaw with Aspect-Ratio of 0.25 and Initial Surface Length of 0.25" to Structural Failure of the Lower Flange When the Lower Flange Material has a Fracture-Toughness of $25 \mathrm{KSI} \sqrt{\mathrm{in}}$

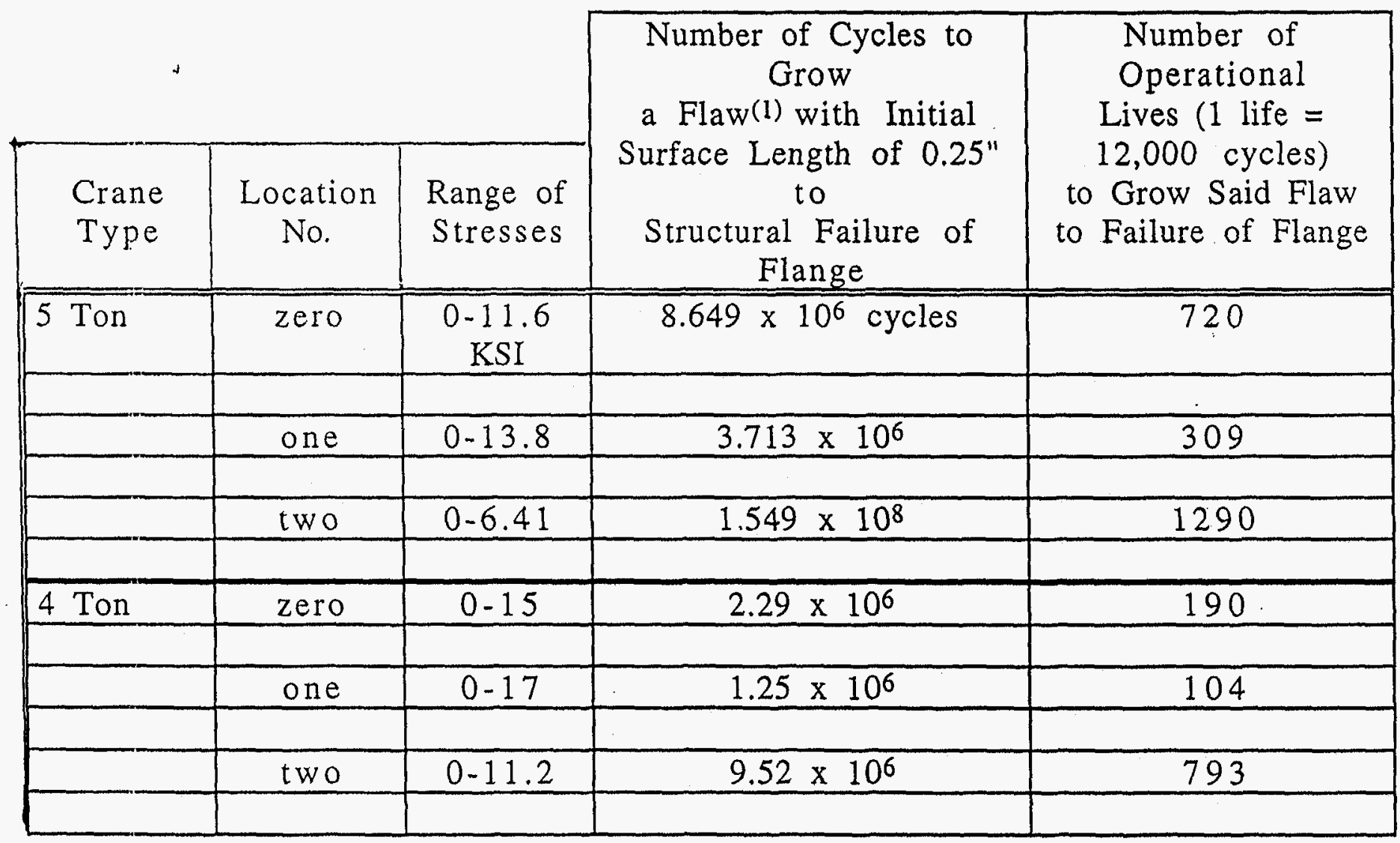

Notes:

(1) Initial flaw is a semi-eliptical surface crack with an aspect ratio of 0.25 and a surface-length of $0.25^{\prime \prime}$ 
Table 5: Margins of Conservatism Introduced in Fracture Mechanics Analyses Based on Initial Flaw-Lengths by Assumption of a Reduced Fracture-Toughness of 25 KSI $\sqrt{\text { in }}$ for A.S.T.M. A.36 Steel Flanges in the Ederer 5 Ton and 4 Ton Cranes in the Device Assembly Facility

\begin{tabular}{|c|c|c|c|c|c|c|c|c|c|c|c|}
\hline \multirow{2}{*}{$\begin{array}{l}\text { Crane } \\
\text { Type }\end{array}$} & \multirow{2}{*}{$\begin{array}{c}\text { Location } \\
\text { No. }\end{array}$} & \multirow{2}{*}{$\begin{array}{l}\text { Range of } \\
\text { Stresses }\end{array}$} & \multicolumn{3}{|c|}{$\begin{array}{c}\text { Initial Flaw-Length to } 2 \\
\text { Cause Failure in Indicated } \\
\text { Number of Cycles, } \\
\text { Norma!-Fracture-Toughness } \\
\text { Case }\end{array}$} & \multicolumn{3}{|c|}{$\begin{array}{c}\text { Initial Flaw Length to } \\
\text { Cause Failure in Indicated } \\
\text { Number of Cycles, } \\
\text { Minimum-Fracture-Toughness } \\
\text { Case }\end{array}$} & \multicolumn{3}{|c|}{$\begin{array}{l}{ }^{4} \text { Margin of Conservatism on } \\
\text { Initial Flaw Length to Cause } \\
\text { Failure in Indicated number } \\
\text { of Cycles }\end{array}$} \\
\hline & & & 200 & 400 & 12,000 & 200 & 400 & 12,000 & 200 & 400 & 12,000 \\
\hline \multirow[t]{4}{*}{5 Ton } & zero & $\begin{array}{c}0.11 .6 \\
\text { KSI }\end{array}$ & $2.9^{\prime \prime}$ & 2.81 & $2.0^{\prime \prime}$ & $2.6^{\prime \prime}$ & $2.5^{\prime \prime}$ & $1.9^{\prime \prime}$ & 0.103 & 0.107 & 0.05 \\
\hline & & & & & & & & & & & \\
\hline & one & $0-13.8$ & $2.75^{\prime \prime}$ & $2.70^{\prime \prime}$ & $1.70^{\prime \prime}$ & $2.5^{\prime \prime}$ & $2.4^{\prime \prime}$ & $1.55^{\prime \prime}$ & 0.091 & 0.111 & 0.088 \\
\hline & two & $0-6.41$ & $3.40^{\prime \prime}$ & $3.30^{\prime \prime}$ & $2.75^{\prime \prime}$ & $3.2^{\prime \prime}$ & $3.1^{11}$ & $2.55^{\prime \prime}$ & 0.059 & 0.061 & 0.073 \\
\hline \multirow[t]{5}{*}{4 Ton } & zero & $0-15$ & $2.05^{\prime \prime}$ & $2.0^{\prime \prime}$ & $1.3^{\prime \prime}$ & $1.8^{\prime \prime}$ & $1.75^{\prime \prime}$ & $1.25^{\prime \prime}$ & 0.122 & 0.125 & 0.038 \\
\hline & & & & & & & & & & & \\
\hline & one & $0-17$ & $1.9^{\prime \prime}$ & $1.8^{\prime \prime}$ & $1.17^{\prime \prime}$ & $1.75^{\prime \prime}$ & $1.70^{\prime \prime}$ & $1.10^{\prime \prime}$ & 0.079 & 0.056 & 0.060 \\
\hline & two & $0-11.2$ & $2.4^{\prime \prime}$ & $2.2^{\prime \prime}$ & $1.6^{\prime \prime}$ & $2.00^{\prime \prime}$ & $1.95^{\prime \prime}$ & $1.60^{\prime \prime}$ & 0.167 & 013 & \\
\hline & & & & & & & & & & & 0. \\
\hline
\end{tabular}

Notes:

(1) For a single semi-eliptical surface-flaw with an aspect-ratio of $\frac{a}{2 C}=0.25$
(2) Normal fracture toughness case: $K_{I C}=45 \mathrm{KSI}$ Yin (Ref. I)

(3) Minimum fracture toughness case: $\mathrm{K}_{I \mathrm{C}}=25 \mathrm{KSI} \sqrt{\mathrm{in}}$ (Ref.)

(4) Margin of Conservatism $=1-$ Initial flaw-length (minimum KIC case) Initial flaw-length (normal KIC case) 
Table 6 Margins of Conservatism Introduced in Fracture Mechanics Analyses Daseu on Final Flaw-Lengths by Assumption of a Reduced Fracture-Toughness of $25 \mathrm{KSI} \sqrt{\mathrm{in}}$ for A.S.T.M. A-36 Steel Flanges in the Ederer 5 Ton and 4

Ton Cranes in the Device Assembly Facility

\begin{tabular}{|c|c|c|c|c|c|c|c|c|c|c|c|}
\hline \multirow{3}{*}{$\begin{array}{l}\text { Crane } \\
\text { Type }\end{array}$} & 1 & & \multirow{2}{*}{\multicolumn{3}{|c|}{$\begin{array}{c}\text { Number of Cycles, } \\
\text { Normal - Fracture-Toughness } \\
\text { Case } \\
\end{array}$}} & \multirow{2}{*}{\multicolumn{3}{|c|}{$\begin{array}{c}\text { Number of Cycles, } \\
\text { Minimum-Fracture-Toughness } \\
\text { Case }\end{array}$}} & \multirow{2}{*}{\multicolumn{3}{|c|}{$\begin{array}{c}\text { Failure in Indicated number } \\
\text { of Cycles }\end{array}$}} \\
\hline & \multirow{2}{*}{$\begin{array}{c}\text { Location } \\
\text { No. }\end{array}$} & \multirow{2}{*}{$\begin{array}{l}\text { Range of } \\
\text { Stresses }\end{array}$} & & & & & & & & & \\
\hline & & & 200 & 400 & 12,000 & 200 & 400 & 12,000 & 200 & 400 & 12,000 \\
\hline \multirow[t]{6}{*}{5 Ton } & \multirow[t]{2}{*}{ zero } & \multirow{2}{*}{$\begin{array}{c}0-11.6 \\
\text { KSI }\end{array}$} & $3.00^{\prime \prime}$ & $3.00^{\prime \prime}$ & $2.10^{\prime \prime}$ & $2.70^{\prime \prime \prime}$ & $2.65^{\prime \prime}$ & $2.00^{\prime \prime}$ & 0.100 & 0.117 & 0.048 \\
\hline & & & & & & & & & & & \\
\hline & & & & & & & & & & & \\
\hline & one & $0-13.8$ & $2.85^{\prime \prime}$ & $2.80^{\prime \prime}$ & $2.00^{\prime \prime}$ & $2.55^{\prime \prime}$ & $2.45^{\prime \prime}$ & $1.85^{\prime \prime}$ & 0.105 & 0.125 & 0.075 \\
\hline & & & & & & & & & & & \\
\hline & two & 0.6 .41 & $3.85^{\prime \prime}$ & $3.70^{\prime \prime}$ & $2.90^{\prime \prime}$ & $3.50^{\prime \prime}$ & $3.40^{\prime \prime}$ & $2.90^{\prime \prime}$ & 0.091 & 0.081 & 0 \\
\hline 4 Ton & zero & $0-15$ & $2.15^{\prime \prime}$ & $2.10^{\prime \prime}$ & $1.50^{\prime \prime}$ & $1.90^{\prime \prime}$ & $1.85^{\prime \prime}$ & $1.40^{\prime \prime}$ & 0.116 & 0.119 & 0.067 \\
\hline & & & & & & & & & & & \\
\hline & one & 0.17 & $2.10^{\prime \prime}$ & $1.90^{\prime \prime}$ & $1.48^{\prime \prime}$ & $1.85^{\prime \prime}$ & $1.75^{\prime \prime}$ & $1.30^{\prime \prime}$ & 0.119 & 0.079 & 0.122 \\
\hline & & & & & & & & & & & \\
\hline & two & 0.11 .2 & $2.50^{\prime \prime}$ & $2.40^{\prime \prime}$ & $1.90^{\prime \prime}$ & $2.10^{\prime \prime}$ & $2.05^{\prime \prime}$ & $1.70 "$ & 0.160 & 0.146 & 0.105 \\
\hline & & & & & & & & & & & \\
\hline
\end{tabular}

Notes:

(1) For a single semi-eliptical surface-flaw with an aspect-ratio of $\frac{\mathrm{a}}{2 \mathrm{C}}=0.25$

(2) Normal fracture toughness case: $K_{I C}=45 \mathrm{KSI}$ Vin (Ret. 1)

(3) Minimum fracture toughness case: $\mathrm{K}_{\mathrm{IC}}=25 \mathrm{KSI} \sqrt{\text { in }}$ (Ref.)

(4) Margin of Conservatism $=1-\frac{\text { Initial flaw-length (minimum } K_{I C} \text { case) }}{\text { Initial flaw-length (normal } K_{I C} \text { case) }}$ 
Table 7: Comparison of Differences in Cyclic Lives for the Normal Fracture Toughness and

Minimum Fracture-Toughness Cases when a Semi-Eliptical Flaw with Aspect-Ratio of 0.25 and

Initial Surface Length of $0.25^{\prime \prime}$ Grows to Failure in Various Locations on the Lower Flange of the

Crane Beams of the Ederer 5 Ten Crane and 4 Ton Crame in the Device Assembly Facility

\begin{tabular}{|c|c|c|c|c|c|c|c|}
\hline \multirow{3}{*}{$\begin{array}{l}\text { Crane } \\
\text { Type }\end{array}$} & \multirow{3}{*}{$\begin{array}{l} \\
\text { Location } \\
\text { No. }\end{array}$} & \multirow{3}{*}{$\begin{array}{l}\text { Range of } \\
\text { Stresses }\end{array}$} & \multirow{3}{*}{$\begin{array}{c}\text { Number of Cycles to } \\
\text { Grow } \\
\text { a Flaw(1) with Initial } \\
\text { Surface Length of } 0.25 " \\
\text { to } \\
\text { Structural Failure of } \\
\text { Flange }\end{array}$} & \multirow{3}{*}{$\begin{array}{c}\text { Number of } \\
\text { Operational } \\
\text { Lives ( } 1 \text { life }= \\
12,000 \text { cycles) } \\
\text { to Grow Said Flaw } \\
\text { to Failure of Flange, } \\
\text { (2) Normal Fracture } \\
\text { Toughness Case }\end{array}$} & \multirow{3}{*}{$\begin{array}{c}\text { Lives (1 life }=12,000 \text { cycles) } \\
\text { to Grow Said Flaw } \\
\text { to Failure of Flange, } \\
\text { (3)Minimum Fracture Toughness } \\
\text { Case }\end{array}$} & \multirow{2}{*}{\multicolumn{2}{|c|}{$\begin{array}{l}\text { Difference in Number of } \\
\text { Operational Lives Between } \\
\text { Normal Fracture-Toughness Case } \\
\text { and Minimum Fracture- } \\
\text { Toughness Case }\end{array}$}} \\
\hline & & & & & & & \\
\hline & & & & & & $\begin{array}{l}\text { (4) Number of } \\
\text { Operational Lives }\end{array}$ & $\begin{array}{l}\text { (5) Percent } \\
\text { Difference } \\
\end{array}$ \\
\hline \multirow[t]{5}{*}{5 Ton } & zero & $\begin{array}{c}0.11 .6 \\
\mathrm{KSI}\end{array}$ & $8.673 \times 10^{6}$ cycles & 722 & 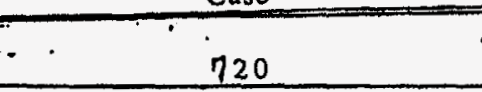 & 2 & 0.277 \\
\hline & & & & $\therefore$ & $T^{-}$ & & \\
\hline & one & 0.13 .8 & $3.727 \times 10^{6}$ & 310 & 309 & 1 & 0.323 \\
\hline & & & & & & & \\
\hline & two & 0.6 .41 & $1.55 \times 10^{8}$ & 1291 & 1290 & 1 & 0.077 \\
\hline \multirow[t]{5}{*}{4 Ton } & zero & 0.15 & $2.292 \times 10^{6}$ & 191 & 190 & 1 & 0.524 \\
\hline & & & & & & & \\
\hline & one & 0.17 & $1.254 \times 10^{6}$ & 104 & 104 & 0 & 0 \\
\hline & & & & & & & 0377 \\
\hline & two & 0.11 .2 & $9.549 \times 10^{6}$ & 796 & 793 & 3 & 0.377 \\
\hline
\end{tabular}

\section{Notes:}

(1) Initial flaw is a semi-elliptical surtace crack with an aspect ratio $\frac{a}{2 c}=0.25$

(2) Normal Fracture-toughness case: $K_{I c}$ of $45 \mathrm{ksirin}$

(3) Minimum fracture toughness case: $K_{\mathrm{lc}}$ of $25 \mathrm{ksin}$

(4) One "operational Life" $=12000$ cycies

(5) $\%$ Difference $=\boldsymbol{A}-\left(\frac{\text { Number of operational lives for minimum } \mathrm{K}_{\mathrm{IC}}}{\text { Number of operational lives for minimum } \mathrm{K}_{\mathrm{IC}}}\right) \times 100$ 


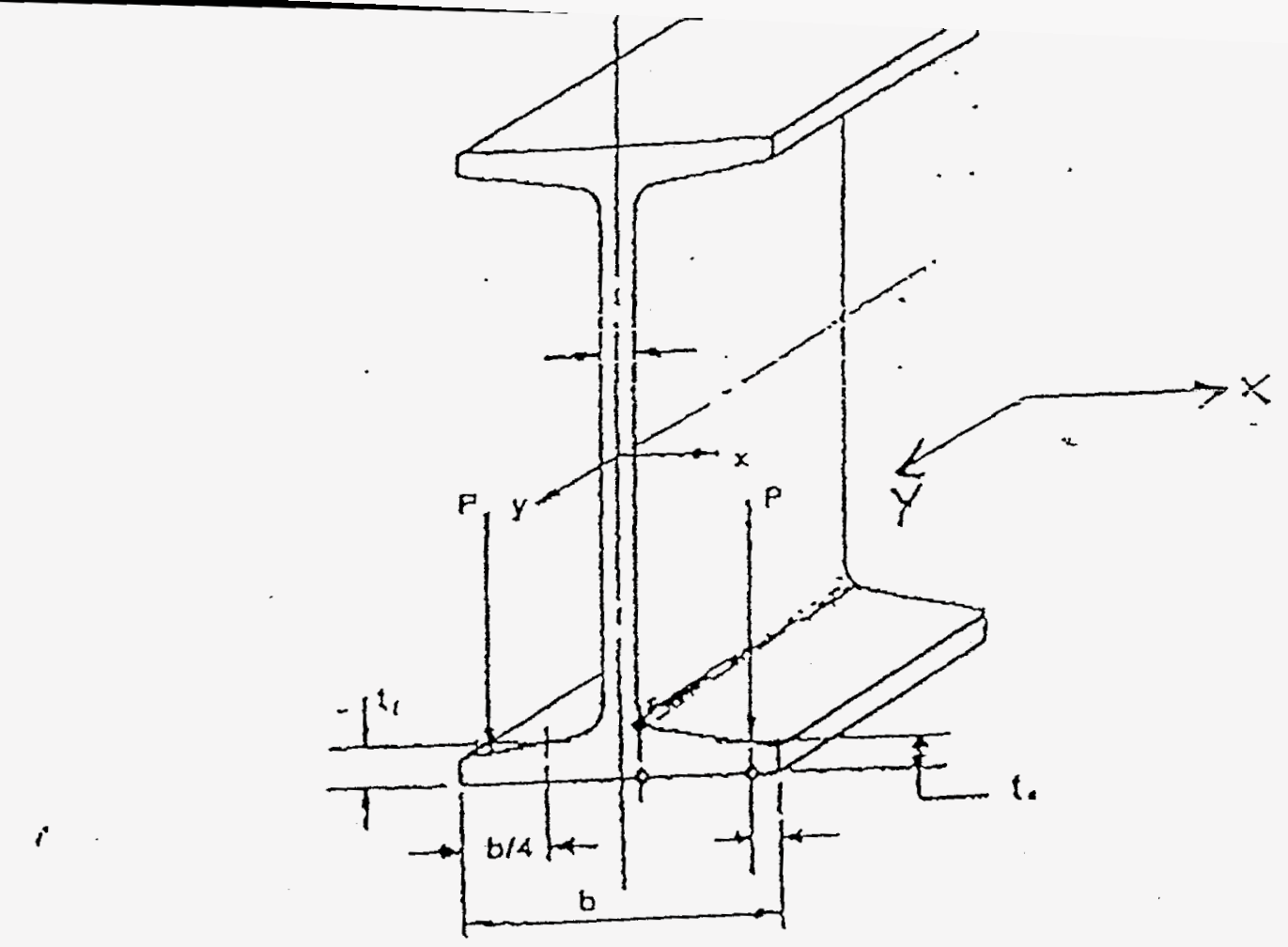

(A) SCHEMATIC OF CROSSECTION OF BEAM

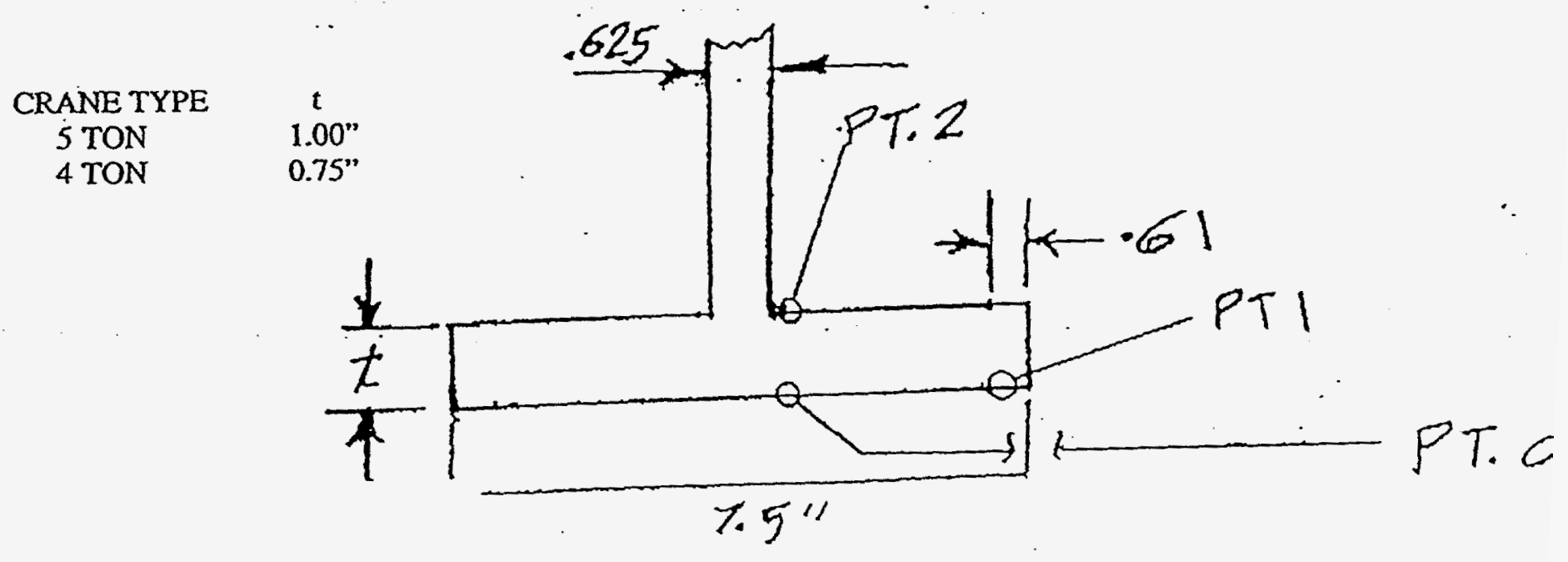

(B) SCHEMATIC OF LOWER FLANGE OF BEAM

FIGURE 1 

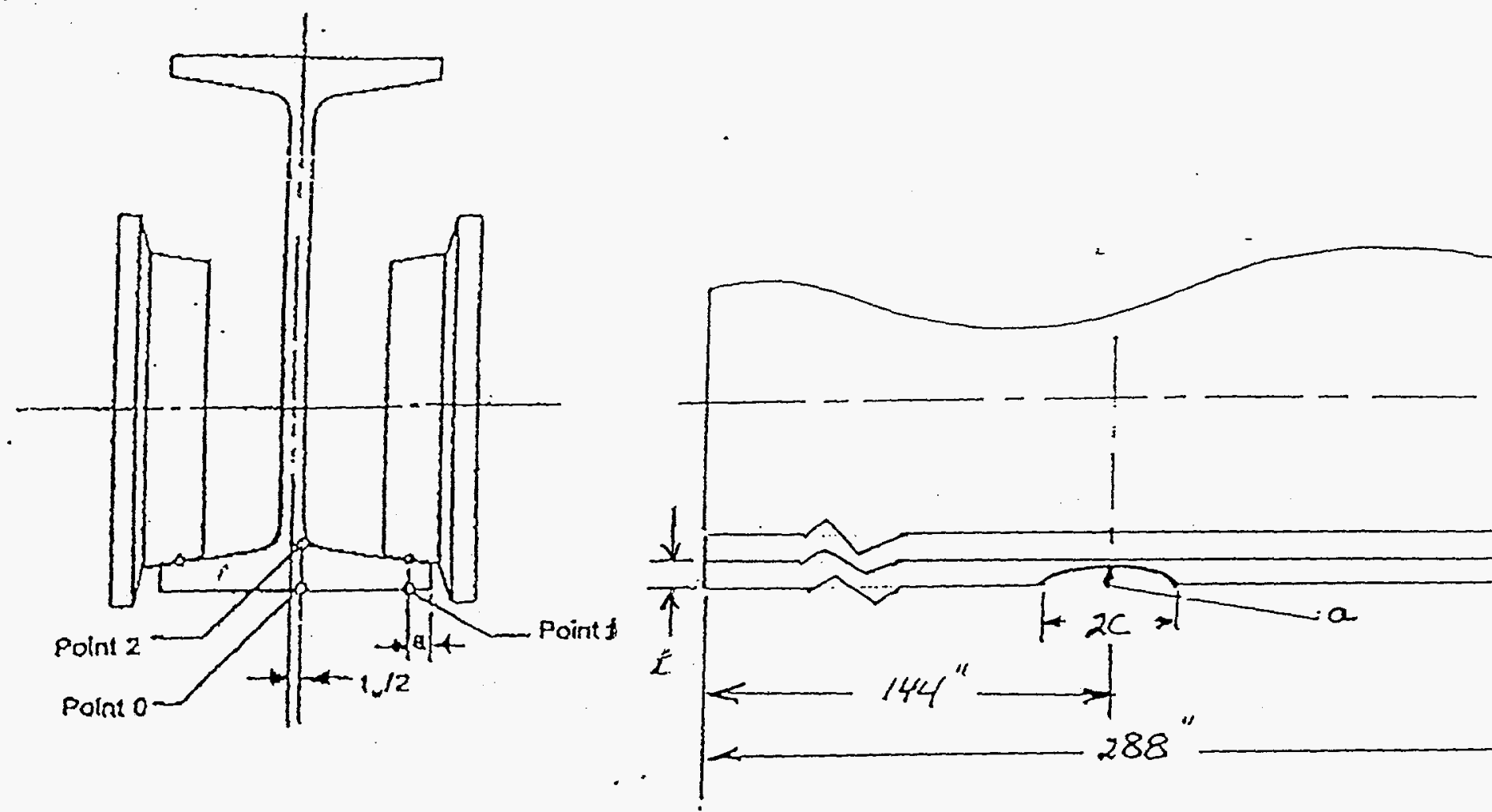

(A) CROSSECTION OF BEAM, SHOWING

(B) LOCATION OF SEMI-ELLIPTICAL SURF CRACK IN FLANGE OF BEAM LOCATIONS OF LOAD-APPLICATION

$\begin{array}{cc}\text { CRANE TYPE } & t \\ 5 \text { TON } & 1.00^{\prime \prime} \\ 4 \text { TON } & 0.75^{\prime \prime}\end{array}$

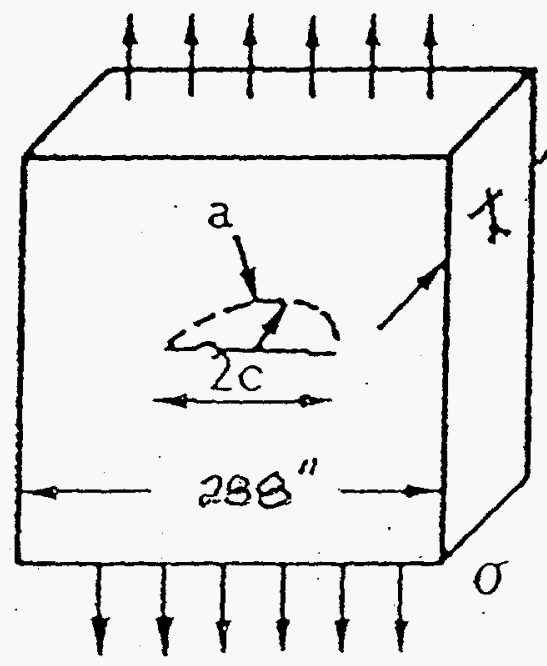

$a / 2 c=0.25$

$\cdots$

(C) SCHEMATIC OF A SEMI-ELLIPTICAL SURFACE CRACK .

DETAILS OF MODEL FLAW AND ITS LOCATION IN LOWER FLANGE OF CRANE-BE 
DIMENSION OF FLAW (INCHES)

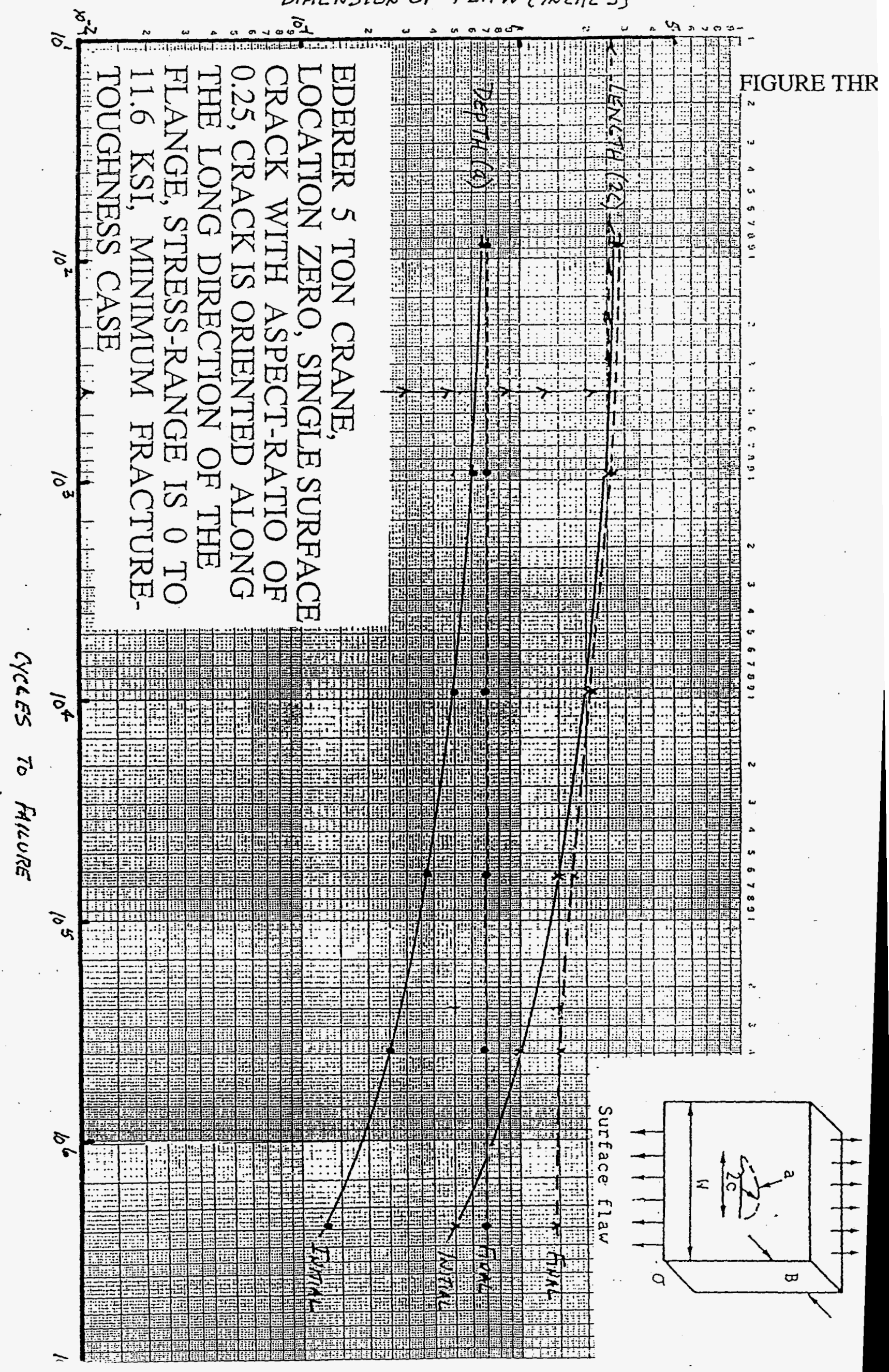




\section{Appendix A - Construction of Materials Design-Allowables for ASTM A-36 Steel Used in Construction of the Ederer Cranes in the Device Assembly Facility (D.A.F.)}

\section{Introduction:}

Steel supplied to recent version of ASTM specification A-36 (A-36-89, Ref. A-1) falls in the category of a "plain carbon", or carbon-steel, and is supplied as rolled structural shapes (angles, channels, and tees, for example), plates, and bars of structural quality for use in riveted, bolted, or welded construction. It is seldom supplied with any type of fracture-toughness requirements. In plate up to 4" thick supplied to earlier versions of ASTM A-36 (Ref. A-2), material could be supplied without having had excess dissolved oxygen removed by liquid-state deoxidation with $\mathrm{Si}$, $\mathrm{Al}$, (or both) to form insoluble particles of oxides called "inclusions". Such steels are called "Rimmed Steels". Partial liquid-state deoxidation is also allowable in plates up to 3/4" thick, and steel so treated is referred to as "semi-killed steel". Plates above 3/4" thick supplied to Ref. 2, and plates above 2" thick supplied to earlier versions of ASTM A-36, are supplied in the fullydeoxidized or "fully-killed" condition. The reasons for the concern about the deoxidation-state of A-36 steel are: (1) The higher the dissolved (soluble) oxygen-content in A-36 steel, the higher is the toughness-transition temperature and the lower will be the upper shelf energy, a measure of ductile fracture-toughness (Ref. A-3); and (2) The higher the inclusion-content (caused by less than complete liquid state deoxidation), the greater will be the directional-dependence of fracturetoughness in the finished product, since large numbers of the oxide inclusions will be elongated in the primary rolling-direction and will serve as semi-continuous paths of easy crack growth in this direction during mechanical loading (Ref. A-3).

How the steel used in manufacture of the cranes D.A.F. were made and whether these heats of steel were evaluated for fracture-toughness is important because both the LLNL Mechanical Engineering Design Safety Standards (Ref. A-4) and the NTED Design Guide (Ref. A-5) mandate the use of a "lower bound plane-strain fracture-toughness" $\left(\mathrm{K}_{\mathrm{Ic}}\right)$ of $25 \mathrm{ksiv}$ in for uncharacterized steels.

A search for fatigue-crack-growth-rate (F.C.G.R.) information yielded the information (Refs. A-4 to A-10) in the form that is plotted in Eqn (A-1) and is presented in Figures A-1 through A-3.

$(A-1)$ F.C.G.R. $=\frac{d a}{d N}=C(\Delta k)^{m}$

where $\mathrm{da}=$ incremental increase in crack-length

$\mathrm{dn}=$ incremental increase in number of load-cycles

$\mathrm{c}, \mathrm{m}=$ material-constants that are fixed for constant material, temperature, and ratio of minimum to maximum load ( $R$ )

$\mathrm{K}=$ Range of stress intensity $=\mathrm{Kmax}-\mathrm{Kmin}=\sigma_{\max }-\sigma_{\min }$

$\sigma=$ applied stress

$a=$ characteristic dimension of crack (or flaw), it may be depth, surface length or half of the surface length.

$\beta=A$ parameter that depends on the geometric constraints of the problem; in particular any angular relationships between the load (or loads) and direction of crack-extension, as well as the geometry of the structure. 
Examination of Figs. A-1 through A-3 indicates that the highest F.C.G.R. data-set is that for hotrolled A-36 steel tested under conditions of $R=0$; i.e.

$(\mathrm{A}-2) \frac{\mathrm{da}}{\mathrm{dN}}=3.93 \times 10^{-12}(\Delta \mathrm{k})^{4.36}$

which is the F.C.G.R. expressed selected for use in the fatigue crack growth analyses.

\section{References}

A-1 Anonymous, "Standard Specification for Structural Steel", Specification A36/A36M-89, American Society for Testing and Materials, Annual Book of ASTM Standards, Vol. 03.01,1990.

A-2 B.M. Kapadia, U.S.S. Division of U.S.X. Corporation, Personal Communication, October 1990.

A-3 G.E. Dieter, "Mechanical Metallurgy", 3rd Edition, McGraw-Hill,- New York, 1986, Pp. 479-81.

A-4 J.J. Scott, Design Safety Standards....Mechanical Engineering Section 5.4."Fracture Critical Components", Pg. 14, Sept. 15, 1995.

A-5 A.M. Davito,"NTED Design Guide", Rpt.M-186,Rev.1,Chapter 3, "Implementation of Fracture Control: Pg 3-3, May 1993.

A-6 J. Barsom, "Fatigue Crack Propagation in Steels of Various Yield Strengths,' Journal of Engineering for Industry (A.S.M.E. Tranasactions, Series B), 93 (4), Nov. 1971

A-7 W. Wilson, W. Clark, Jr., and E. Wessel, "Fracture Mechanics

Technology for Combined Loading and Low-To-intermediate Strength Metals," Technical Report No. 10276 (final) to U.S. Army TACOM, November 18,1968, Pp. 17-19

A-8 J. Baldwin, Jr. and J. Cooper, "Relation of Toughness Test -Values to Fatigue Cracking of Bridges," Report No. FHWA/Mo-78/2, to Missouri Highway and Transportation Department, August 1981, Pp. 32-36

A-9 R. Stephens, P. Benner, G. Maudtzson, and G. Tindall, 'Constant and Variable Amplitude Fatigue of Eight Steels" Journal of Testing and Evaluation, 7 (2), March 1979, Pp. 68-81

A-10 N. Yadzani and P. Albrecht, 'Crack Growth Rates of Structural Steel in Air and Aqueous Environments," Engineering Fracture Mechanics, 32 (6), 1989, Pp. 997-1007

A-11 G. Rading, "The Effect of Welding on the Fatigue Crack Growth Rate in a Structural Steel", Welding Journal, 72 (7), July 1993, Pp. 307s-312s.

A-12 H. Iguchi, K. Tanaka, and S. Taira, "Failure Mechanisms in Impact Fatigue of Metals", Fatigue of Engineering Materials and Structures, 2, 1979, Pp. 165-176. 


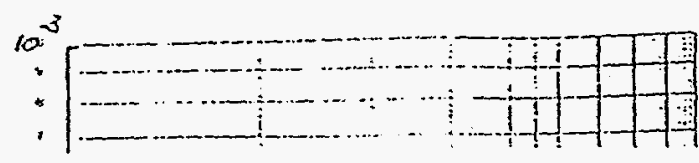

FIGURE A-1

ROOM-TEMPERATURE FATIGUE-CRACK GROWTH BEHAVIOR OF A.STM A-S6 STEEL AND EQUTVALENT MATERTALS

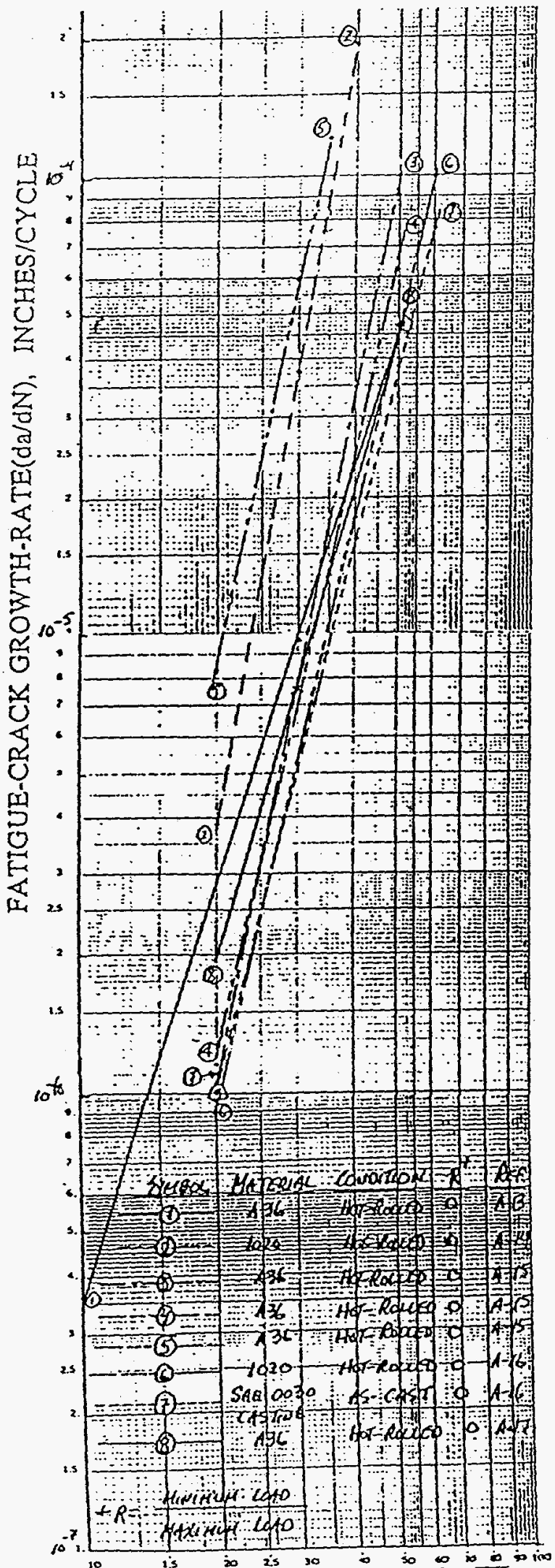

FIGURE A-2

EFFECT OF LOAD-RATIO ON ROOMTEMPERATURE FATIGUE-CRACK

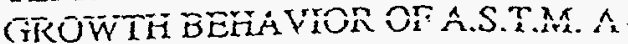
STEEL AND EQUTVALENT MATERLA

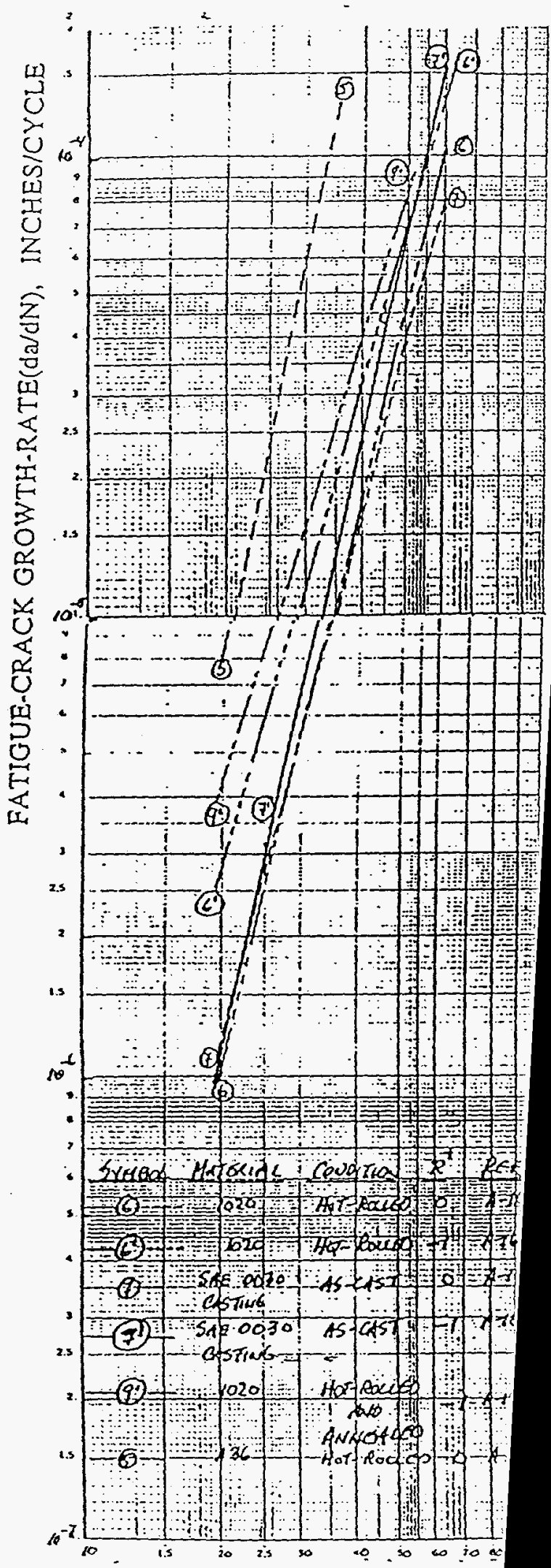




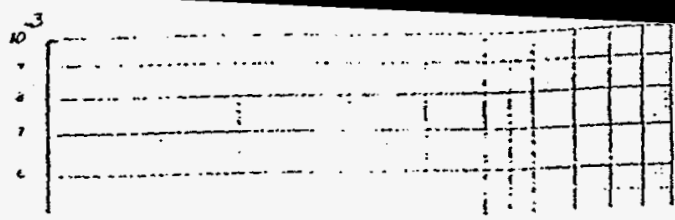

FIGURE A-3

EFFECT OF FUSION WELDNG ON TUE POOM TEMPERATURE FATIGUE-CRACK GROWTH-RATE OF A.S.T.M. A-36 STEEL AT FIXED LOAD-RATIOS

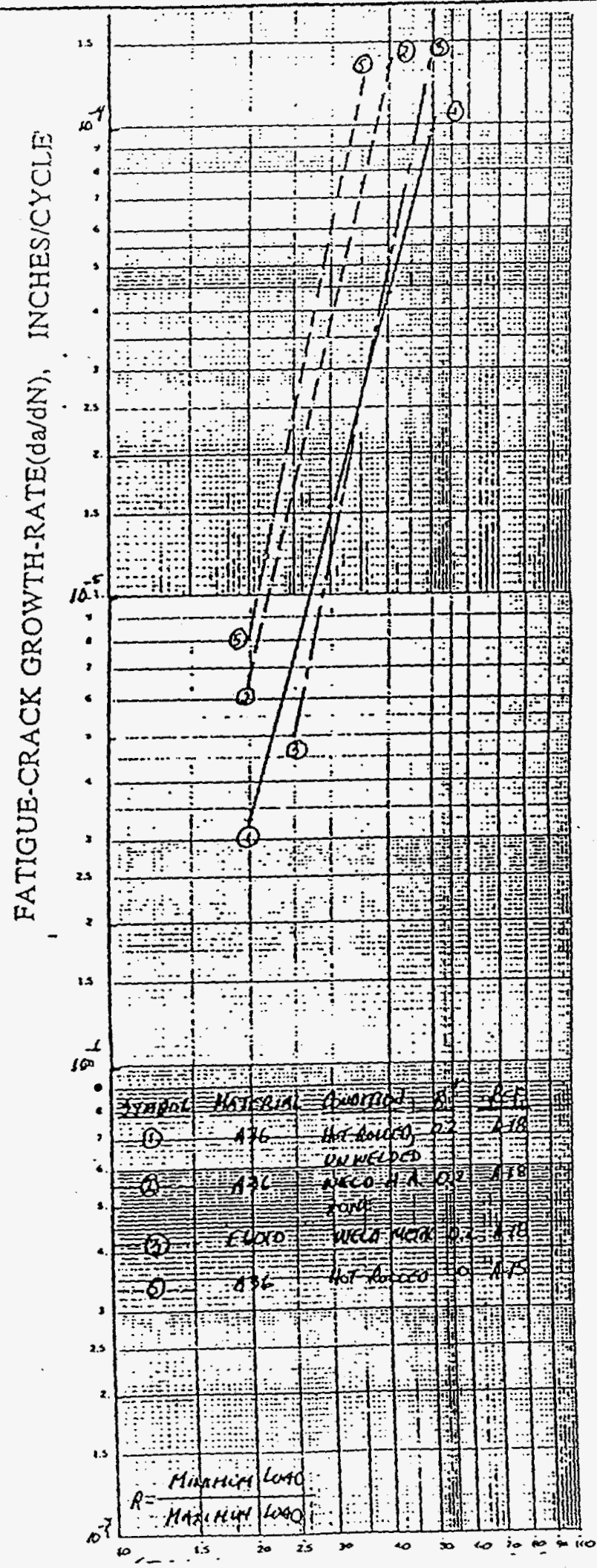

STRESS-INTENSITY RANGE( $\triangle \mathrm{K}), \mathrm{KSI} / \mathrm{IN}$ 
Appendix $\bar{B}$ Pilots of Fiaw-Dimension Versus Cycles io Failure for Eocicrer Cranes

.

$i$ 
DIMENSLON OF FLAW (INCHES)

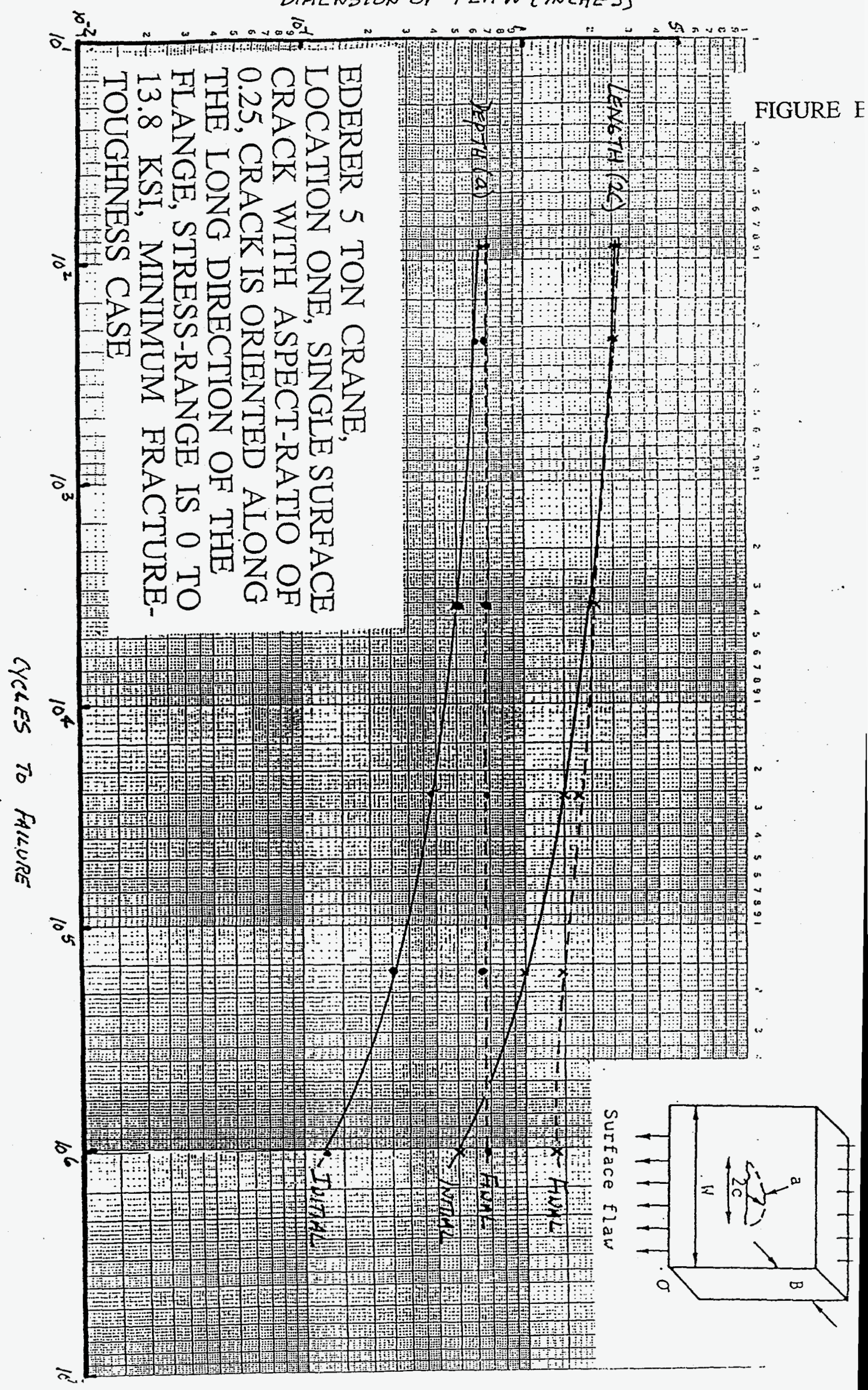




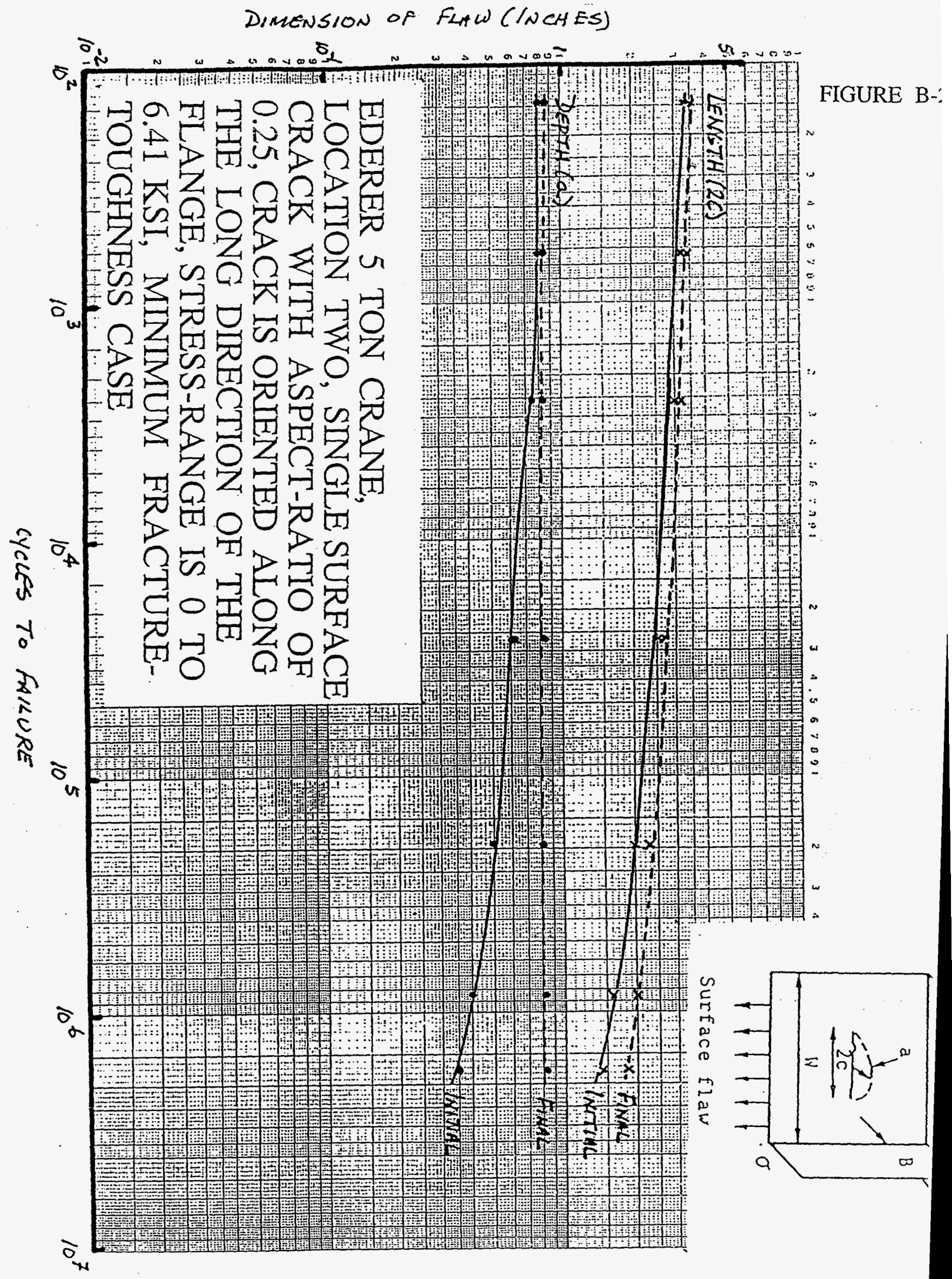


DIRENESION OF FLAW (INCHES)

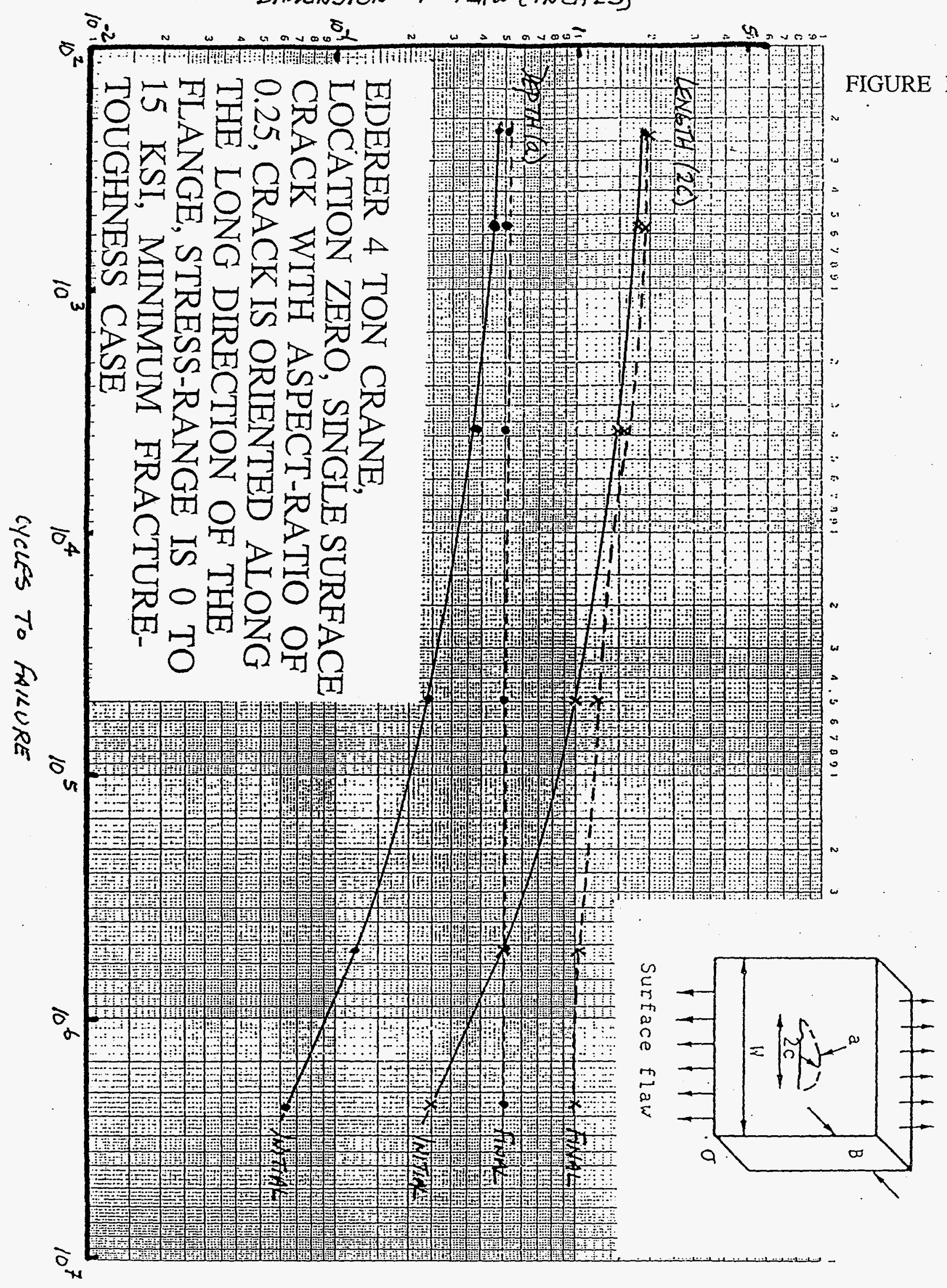


DIMENSION of FLAW (NNCHES)

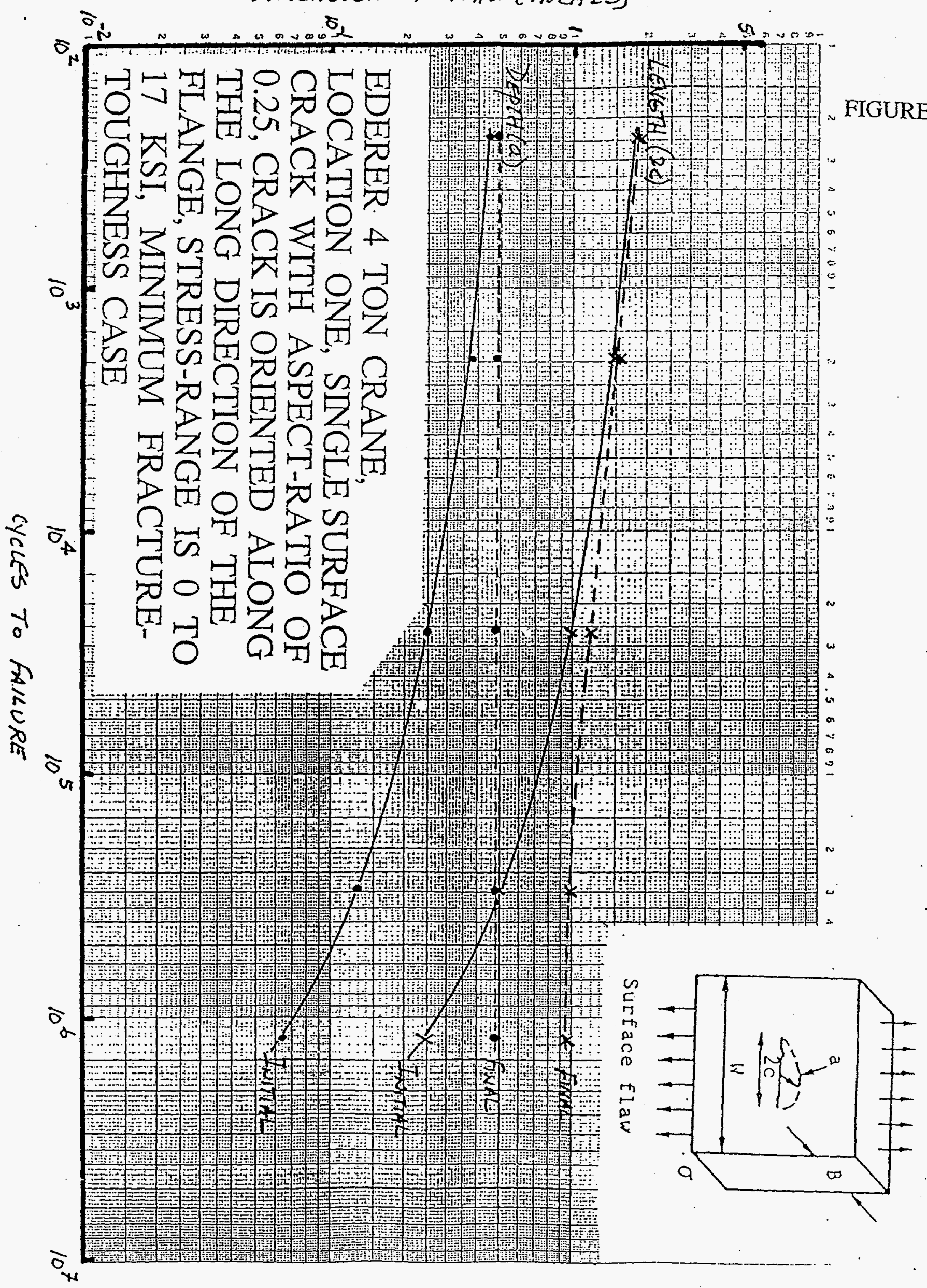


